\title{
The overprescription of antidepressants and its impact on the elderly in Australia
}

\author{
Prescrição excessiva de antidepressivos e seu impacto em idosos na Austrália
}

Muath Alduhishy

\begin{abstract}
Introduction: Psychopharmaceutical medications are noted for being one of the most commonly prescribed drugs worldwide, which makes the issue of overprescribing them such a heated topic in medicine and psychiatry today.

Method: A literature review was made to investigate the topic of psychotropic medication prescriptions. The scope intended here is specific to antidepressant use, or rather overuse, in Australia, but it can be compared to the use of other psychotropic drugs in most western countries. The focus is directed towards the most vulnerable group of patients: the elderly.

Results: The past few decades have witnessed a surge in the use of psychotropic drugs, most notably antidepressants, in Australia and worldwide. This has numerous reasons as well as consequences, especially on vulnerable members of society.

Conclusion: It has been suggested that overprescription of antidepressants is fueled by the increase in the incidence of depression, stress and anxiety, or due to the way psychotropic medications are marketed. However, regardless of the validity of the said reasons, another explanation could be suggested: psychiatric disorders, namely depression, are being overdiagnosed on a considerable scale, probably leading to a list of significant adverse consequences that mostly affect the most vulnerable groups of patients. At the end, further rigorous research should certainly be undertaken to examine the extent and cost of overprescription of psychotropic drugs in society.
\end{abstract}

Keywords: Antidepressants, medications, depression, overuse, overprescription, elderly.

\section{Resumo}

Introdução: Os psicofármacos estão entre as medicações mais frequentemente prescritas no mundo todo, tornando o assunto da prescrição excessiva um assunto polêmico na medicina e na psiquiatria nos dias atuais.

Método: Foi feita uma revisão da literatura para investigar o tópico das prescrições dos medicamentos psicotrópicos. O escopo pretendido aqui é especificamente o uso de antidepressivos, ou melhor, seu uso excessivo, na Austrália, mas ele pode ser comparado ao uso de outros medicamentos psicotrópicos na maioria dos países ocidentais. O foco é direcionado ao grupo mais vulnerável de pacientes: os idosos.

Resultados: As últimas décadas testemunharam um aumento no uso de drogas psicotrópicas, principalmente antidepressivos, na Austrália e no mundo todo. Isso tem várias razões e também consequências, especialmente nos membros vulneráveis da sociedade.

Conclusão: Tem sido sugerido que a prescrição excessiva de antidepressivos é motivada pelo aumento na incidência de depressão, stress e ansiedade, ou devido à forma como as medicações psicotrópicas são comercializadas. No entanto, independentemente da validade das razões apontadas, outra explicações poderia ser sugerida: transtornos psiquiátricos, especialmente depressão, têm sido sobrediagnosticados em uma escala considerável, provavelmente levando a uma lista de consequências adversas significativas que afetam principalmente os grupos mais vulneráveis de pacientes. Afinal, pesquisas rigorosas deveriam ser conduzidas para examinar a extensão e o custo da prescrição excessiva de medicamentos psicotrópicos na sociedade.

Descritores: Antidepressivos, medicamentos, depressão, uso excessivo, prescrição excessiva, idosos. 


\section{Introduction}

Psychopharmaceutical medications are noted for being one of the most commonly prescribed drugs worldwide, ${ }^{1}$ which makes the issue of overprescribing them such a heated topic in medicine and psychiatry today. As a clear evidence of their overuse, the last decade or so has witnessed a significant growth in the dispensing of psychotropic drugs in Australia, with an over $58 \%$ rate of increase from the years 2000 to 2011.2 Additionally, the use of psychopharmaceutical drugs is seen to be ballooning in almost all industrialized nations of the world. For example, in France, which has the highest consumption rate globally, a quarter of the population is using at least one psychotropic agent, ${ }^{3}$ which shows that it is indeed an international issue with potentially serious ramifications on the safety of patients and the cost of healthcare worldwide. Therefore, it is not an exaggeration to say that this issue should interest and concern the governments and healthcare authorities along with health professionals and lay people.

\section{Antidepressants}

Antidepressants, in particular, offer the mostapparent example of psychopharmaceutical overprescription, given their widespread use: they alone represent nearly $5 \%$ of all medications prescribed in primary care in Australia. ${ }^{4}$ This class of drugs is also dispensed more rapidly than any other class of psychotropic medications, with an almost two-fold increase since the start of this century. ${ }^{2}$ This could be attributed to an upsurge in the incidence of depression, increased public awareness regarding it, or both. ${ }^{5}$ However, many commentators would argue differently, chiefly because studies have revealed that antidepressants may show minimal, or non-existent, efficacy with mild to moderate levels of the disease, which most depressed patients have.6-8 In such cases, psychotherapy, e.g., cognitive behavioral therapy (CBT), and supportive clinical care, including psychoeducation and teaching the patient certain skills of problem-solving, are the first-line of therapy according to the Australian and New Zealand Clinical Practice Guidelines for the Treatment of Depression. ${ }^{9}$ Moreover, interestingly, the varieties of antidepressant medications available for patients have changed only very slightly in the past decade, and are not likely to be "revolutionized" in the near future. ${ }^{2}$ It is not a secret that we still have a relatively poor knowledge and understanding of the causes of most, if not all, psychiatric disorders. Unfortunately, many drug companies would market ostensibly 'brand-new' antidepressant drugs, where, in reality, they have the same active metabolites of older drugs already found in the market. Regardless of what such companies claim, the efficacy results of these drugs are, at best, marginally enhanced. ${ }^{10}$ In the light of this, such behaviour could be deemed opportunistic. Drug companies are sometimes accused of taking advantage of the situation, since both patients and doctors are eager to find the "magic pill" to treat depression with its debilitating symptoms.

\section{The issue of overuse}

Surprisingly, a poor alignment has been discovered between the prevalence of psychological disorders and the prescription of antidepressant drugs. It has been shown that the dramatic increase in the use of antidepressants does not necessarily address an increase in the diagnosis of depression or other related psychological disorders that they intend to treat. ${ }^{10}$ In turn, this suggests that different factors are behind the current overprescription other than the patient's health needs. As it would be expected, the demographic group most strongly affected by the overuse of psychotropic agents is the elderly, especially those older than 80 years of age, who happen to be the most vulnerable group to drug adverse reactions. ${ }^{11}$ This leads us to discuss the negative outcomes signifying the issue between our hands.

\section{Adverse consequences}

Overuse of psychiatric medications, including the aforementioned antidepressants, does not come without a cost. In fact, it is a hefty cost indeed. Numerous and significant harms can manifest with it, most obviously the financial burden on the patient and the taxpayers alike, ${ }^{12}$ as well as opportunity costs, where the chances of clinicians and patients working together to find alternative treatment are cut short and might even be completely neglected. ${ }^{13}$ In addition, adverse iatrogenic outcomes of pharmacological agents, including toxicity and unpleasant side effects, should always be considered, especially concerning the most vulnerable demographics of the population. In fact, a massive study involving 60,000 people older than 65 years of age has concluded that the absolute risks for all-cause mortality over 1 year increase with the use of antidepressants. ${ }^{14}$ It should be noted here that this was a population-based cohort 
study, which makes it more prone to confounders and bias, such as channeling bias; however, this does not completely discard the conclusions drawn from the study. The main one would be that there is a pattern of association between prescribing antidepressant drugs and the said adverse outcomes, namely in older populations.

Nonetheless, another study has given us further evidence to support such conclusions. Arfken et al. demonstrated that antidepressants, specifically selective serotonin reuptake inhibitors like Prozac and Zoloft, are associated with a more than two-fold rise in the risk of falls in older adults ( $\geq 60$ years). ${ }^{15}$ As a result, compared to the general public, the risk of injury, either minor or major, as well as of severe bleeding and significant neurological and musculoskeletal trauma, is increased at an alarming rate. Such injuries and traumas are particularly dangerous and potentially fatal in this age group. Of course, additional studies with more rigorous design should definitely be conducted to investigate these findings further to try and measure the extent of this issue on other physically and mentally vulnerable groups of the society.

\section{Conclusion}

The past few decades have evidently witnessed a skyrocketing use of psychotropics in general and of antidepressants in particular. Numerous reasons have been offered to justify this phenomenon, such as that depression is getting more common, stress and anxiety are increasing, or pharmaceutical corporations are fiercely marketing their products. However, regardless of the validity of the said reasons, another explanation could be suggested: psychiatric disorders, namely depression, are being overdiagnosed on a considerable scale. The result of that is a list of significant adverse consequences that more notably affect the most vulnerable group of patients: the elderly. At the end, further rigorous research should certainly be undertaken to examine the extent and cost of overprescription of psychotropic drugs in society.

\section{Disclosure}

No conflicts of interest declared concerning the publication of this article.

\section{References}

1. Britt H, Miller MG, Henderson J, Charles J, Valenti L, Harrison C, et al. General practice activity in Australia 2011-12. Sydney: Sydney University Press; 2012.

2. Stephenson CP, Karanges E, McGregor IS. Trends in the utilisation of psychotropic medications in Australia from 2000 to 2011. Aust N Z J Psychiatry. 2013;47:74-87.

3. Lasserre A, Younès N, Blanchon T, Cantegreil-Kallen I, Passerieux C, Thomas G, et al. Psychotropic drug use among older people in general practice: discrepancies between opinion and practice. $\mathrm{Br}$ J Gen Pract. 2010;60:e156-62.

4. Britt H, Miller GC, Henderson J, Bayram C, Harrison C, Valenti L, et al. General practice activity in Australia 2013-14: Sydney University Press; 2014.

5. Partridge B, Lucke J, Hall W. Public attitudes towards the acceptability of using drugs to treat depression and ADHD. Aust N Z J Psychiatry. 2012;46:958-65.

6. Zimmerman M, Posternak MA, Chelminski I. Symptom severity and exclusion from antidepressant efficacy trials. J Clin Psychopharmacol. 2002;22:610-4.

7. Kirsch I, Deacon BJ, Huedo-Medina TB, Scoboria A, Moore TJ, Johnson BT. Initial severity and antidepressant benefits: a metaanalysis of data submitted to the Food and Drug Administration. PLoS Med. 2008; 5:e45.

8. Fournier JC, DeRubeis RJ, Hollon SD, Dimidjian S, Amsterdam JD, Shelton RC, et al. Antidepressant drug effects and depression severity: a patient-level meta-analysis. JAMA. 2010;303:47-53.

9. Australian and New Zealand clinical practice guidelines for the treatment of depression. Aust N Z J Psychiatry. 2004;38:389407.

10. Hollingworth SA, Burgess PM, Whiteford HA. Affective and anxiety disorders: prevalence, treatment and antidepressant medication use. Aust N Z J Psychiatry. 2010;44:513-9.

11. Cresswell KM, Fernando B, McKinstry B, Sheikh A. Adverse drug events in the elderly. Br Med Bull. 2007;83:259-74.

12. Zuvekas SH. Prescription drugs and the changing patterns of treatment for mental disorders, 1996-2001. Health Aff (Millwood). 2005;24:195-205.

13. Siriwardena AN. Why do GPs prescribe psychotropic drugs when they would rather provide alternative psychological interventions? Br J Gen Pract. 2010;60:241-2.

14. Coupland C, Dhiman P, Morriss R, Arthur A, Barton G, HippisleyCox J. Antidepressant use and risk of adverse outcomes in older people: population based cohort study. BMJ. 2011;343:d4551.

15. Arfken CL, Wilson JG, Aronson SM. Retrospective review of selective serotonin reuptake inhibitors and falling in older nursing home residents. Int Psychogeriatrics. 2005;13:85-91.

\section{Correspondence:}

Muath Alduhishy

Mental Health Department, Rockhampton Hospital

Canning St., Rockhampton

QLD 4701 - Australia

E-mail: dr.alduhishy@gmail.com 